\title{
$\begin{array}{lllllllllllllllll}\mathbf{R} & \mathbf{O} & \mathbf{Z} & \mathbf{P} & \mathbf{R} & \mathbf{A} & \mathbf{W} & \mathbf{Y} & \mathbf{I} & \mathbf{A} & \mathbf{R} & \mathbf{T} & \mathbf{Y} & \mathbf{K} & \mathbf{U} & \mathbf{L} & \mathbf{Y}\end{array}$
}

Prawo Kanoniczne

$58(2015) \mathrm{nr} 2$

KS. GINTER DZIERŻON

Wydział Prawa Kanonicznego

Uniwersytetu Kardynała Stefana Wyszyńskiego w Warszawie

\section{FORMA DEKRETU POSZCZEGÓLNEGO \\ W KANONICZNYM PORZACKU PRAWNYM \\ (KAN. 51 KPK)}

Treść: Wstęp. - 1. Pisemność dekretu. - 2. Motywacja dekretu. - Zakończenie.

\section{Wstęp}

W Rozdziale II Tytułu III Księgi „Norm Ogólnych” poświęconego problemowi dekretów poszczególnych i nakazów w kan. 51 KPK ustawodawca odniósł się do kwestii formy dekretu poszczególnego stwierdzając: „Dekret powinien być wydany na piśmie, z podaniem jeśli zawiera decyzję, przynajmniej ogólnej motywacji”. Analizując wstępnie zapis tej normy należy skonstatować, że zostały w niej zawarte dwa zasadnicze wątki, jakimi są: pisemność dekretu oraz jego motywacja.

\section{Pisemność dekretu}

Nawiązując do generalnej teorii aktu prawnego, której poszczególne elementy zostały wyartykułowane w kan. $124 \$ 1 \mathrm{KPK}$ należy zwrócić uwagę, że prawodawca nie wyklucza wprowadzenia w strukturę aktu elementów formalnych ${ }^{1}$. Taki charakter ma wymóg

\footnotetext{
${ }^{1}$ Szerzej na ten temat zob. G. DzIerżon, Niezdolność do zawarcia małżeństwa jako kategoria kanoniczna, Warszawa 2002, s. 50-51.
} 
określony w kan. 51 KPK co do pisemności dekretu poszczególnego². Bezpośrednim źródłem tego kanonu jest pierwsze zdanie kan. $6 \$ 2$ „Schematu kanonów procedury administracyjnej” (Schema canonum de procedura administrativa) w którym czytamy, że dekret powinien być wydany na piśmie ${ }^{3}$. Wobec takich zapisów nie ma wątpliwości co do tego, że wydanie takiego aktu w kanonicznym porządku prawnym ma charakter formalny. Wymóg ten wpisuje się organicznie w założenia generalne co do pisemności poszczególnych aktów administracyjnych skodyfikowane w kan. 37 KPK, zawartym w „Normach wspólnych” Tytułu III. W regulacji tej postanowiono, że „akt administracyjny dotyczący zakresu zewnętrznego powinien być wydany na piśmie". Należy zauważyć, iż zapis kan. 51 KPK jest koherentny z zapisem kan. $37 \mathrm{KPK}^{4}$. Wobec takiego stanu prawnego powstaje wątpliwość: czy wprowadzenie kan. 51 KPK było zasadne? Wątpliwość ta jest w pełni usprawiedliwiona ze względu na to, że regulacje występujące w „Normach wspólnych” mają, jak to określił J. Miras, szczególne znaczenie w interpretacji norm zawartych w rozdziałach od II - V Tytułu III Księgi „Norm Ogólnych”. Wydaje się, iż wprowadzenie kan. $51 \mathrm{KPK}$ jest $\mathrm{w}$ pewnym sensie uzasadnione ze względów pragmatycznych. Nie wszyscy bowiem stosujący prawo

\footnotetext{
${ }^{2}$ Por. T. Amann, Der Verwaltungsakt für Einzelfälle, St. Ottilien 1997, s. 33; J. MIras, J. Canosa, E. Baura, Compendio de derecho administrativo canónico, Pamplona 2001, s. 145.

${ }^{3}$ Por. Pontificia Commisio Codici Iuris Canonici Recognoscendo, Schema canonum de procedura administrativa, Typis Polyglotis Vaticanis 1972, s. 10. Dalej SCPA: „Decretum scripto feratur [...]”; H. SocHA, Allgemeine Normen, w: Münsterischer Kommentar zum Codex Iuris Canonici, red. K. Lüdicke, t. 1, Essen 1985, ad 51,1 .

${ }^{4}$ Por. E. Labandeira, Trattato di diritto amministrativo canonico, Milano 1994, s. 381; J. Miras, J. Canosa, E. Baura, Compendio, dz. cyt., s. 145; J. Krukowski, Komentarz do kan. 51 KPK, w: J. Krukowski, R. Sobański, Komentarz do Kodeksu Prawa Kanonicznego, t. 1, Poznań 2003, s. 114-115.

${ }^{5}$ Por. J. Miras, De actibus administrativis singularibus. Introducción, w: Comentario exegético al Código de Derecho Canónico, red. A. Marzoa, J. Miras, R. Rodríguez-Ocaña, t. 1, Pamplona 1996, s. 498-499.
} 
w kanonicznym porządku prawnym znają dostatecznie funkcjonujące w nim rozwiązania systemowe.

$\mathrm{W}$ analizie poruszanej kwestii nie można też pominąć pytania o walor zapisu co do pisemności dekretu? Komentatorzy pytają: czy wymóg określony w kan. $51 \mathrm{KPK}$ jest wymogiem wymaganym do ważności aktu, czy też jest wymogiem wymaganym jedynie do godziwości? Ustosunkowując się do tego problemu P. Pinto stwierdził, iż dekret powinien być wydany na piśmie; jednak warunki określone w kan. 51 KPK nie są warunkami wymaganymi do ważności aktú. Twierdzenie to jest zasadne, gdyż kan. 51 KPK nie spełnia wymogów określonych w kan. 10 KPK odnoszącego się do kategorii ustaw unieważniających i uniezdalniających. W kan. $51 \mathrm{KPK}$ bowiem prawodawca nie postanowił wyraźnie, że naruszenie dyspozycji o której mowa będzie skutkowało nieważnością aktu. Większość komentatorów stoi zatem na stanowisku, że pisemność nie jest warunkiem wymaganym do ważności dekretu?.

W tym miejscu należy podkreślić z całym naciskiem, iż z punktu widzenia prawa administracyjnego wypełnienia tego warunku nie należy bagatelizować, ponieważ pisemność dekretu z jednej strony jest gwarantem pewności i bezpieczeństwa aktów administracyjnych ${ }^{8}$, z drugiej zaś jest konieczna dla celów dowodowych?.

Pomimo tak skonstruowanego zapisu niektórzy kanoniści jednak przekonują, iż wypełnienie tego wymogu jest warunkiem bezwzględnym. Autorzy „Compendio de derecho administrativo canónico” stoją na stanowisku, że w tym wypadku prawodawca nie przewiduje innej możliwości ${ }^{10}$. Popierając to twierdzenie powołują się na kan. $54 \$ 2$ KPK w którym ustawodawca odnosząc się do problemu notyfikacji

\footnotetext{
${ }^{6}$ Por. P. Pinto, De normis generalibus, w: Commento al Codice di Diritto Canonico, red. P. Pinto, Città del Vaticano 2001, s. 39.

${ }^{7}$ Por. W. Aymans, K. Mörsdorf, Kanonisches Recht, t. 1, Padeborn - München Wien - Zürich 1991, s. 240; P. Lombardía, Commento al can. 51 CIC, w: Codice di Diritto Canonico e le leggi complementari, red. J. Arrieta, Roma 2007, s. 103.

${ }^{8}$ J. Miras, J. Canosa, E. Baura, Compendio, dz. cyt., s. 145.

${ }^{9}$ H. Socha, Allgemeine Normen, dz. cyt., ad 51, 3.

${ }^{10}$ J. Miras, J. Canosa, E. Baura, Compendio, dz. cyt., s. 197.
} 
dekretu postanowił, że następuje ona w momencie doręczenia dokumentu. Twierdzą oni, jeśli doręczenie dokumentu nie miałoby miejsca, wówczas dekret prawnie byłby nieskuteczny ${ }^{11}$.

Należy spostrzec, iż autorzy hiszpańskiego podręcznika w swych analizach nie do końca są konsekwentni. Rozwijając bowiem poruszany wątek uważają, iż odrębnie należy rozpatrzyć każdą normę $\mathrm{z}$ aspektu konsekwencji jakie mogłyby wyniknąć z pominięcia pisemności aktu. W związku z tym przytaczają takie regulacje, jak kan. 156, $179 \$ 3,190 \$ 3,268 \$ 1 \mathrm{KPK}$ jednocześnie wskazując, że w normach tych zostały określone następstwa pominięcia pisemności ${ }^{12}$. Nie do końca można zgodzić się z tymi twierdzeniami. Zapisy bowiem wszystkich tych kanonów są podobne do tych, które występują w kan. 37 i $51 \mathrm{KPK}^{13}$; z nich zaś nie wynika wyraźnie, że idzie o ustawy unieważniające.

Przeciwko tej opcji interpretacyjnej występuje także T. Amann. Uważa on, iż treść kan. $51 \mathrm{KPK}$ nie ma charakteru ustawy unieważniającej. W swej argumentacji powołał się on na kan. 40 i $58 \$ 2 \mathrm{KPK}$. Zacytowany kan. 40 KPK ma nieco inną konstrukcję. Postanowiono w nim, że wykonawca aktu administracyjnego działa nieważnie przed otrzymaniem pisma i sprawdzeniem jego autentyczności. Regulacja ta, w przeciwieństwie do kan. $51 \mathrm{KPK}$, jest typową ustawą uniezdalniającą. Z kolei w kan. $58 \$ 2 \mathrm{KPK}$ zakłada się, że nakaz poszczególny, który jest przecież dekretem (kan. $49 \mathrm{KPK}$ ), nie musi być wydany na

\footnotetext{
${ }^{11}$ Tamże.

12 Tamże.

${ }^{13}$ Zapisy cytowanych kanonów są następujące: kan. 156 KPK: „Każde powierzenie urzędu powinno być dokonane na piśmie”; kan. 179 \$3 KPK odnoszący się do wyboru wymagającego zatwierdzenia: „Zatwierdzenie należy dać na piśmie”; kan. $190 \$ 3$ KPK: „Aby przeniesienie osiągnęło skutek, musi być przekazane na piśmie” (scripto intimanda est); kan. $268 \$ 1 \mathrm{KPK}$ : „Duchowny, który przesiedlił się zgodnie z prawem z własnego Kościoła partykularnego do innego, po upływie pięciu lat zostaje na mocy samego prawa inkardynowany do tego Kościoła partykularnego, jeśli taką wolę wyraził na piśmie, zarówno biskupowi diecezjalnemu Kościoła goszczącego, jak i własnemu biskupowi diecezjalnemu i żaden z nich nie wyraził na piśmie sprzeciwu w ciągu czterech miesięcy od otrzymania pisma”.
} 
piśmie $^{14}$. Z tego wynika, iż w systemie kanonicznym skuteczność prawną mogą uzyskać decyzje podejmowane ustnie.

Przy tym należy zauważyć, iż charakter ustawy unieważniającej ma kan. 474 KPK, dotyczący aktów kurii diecezjalnej. W kanonie tym ustawodawca stwierdził, że akta kurii diecezjalnej aby uzyskać skuteczność prawną do ważności powinny być wydane na piśmie. Zgodnie z tym zapisem, akt wydany bez podpisu ordynariusza jest nieważny ${ }^{15}$. W opinii komentatorów, wprowadzenie tego szczególnego rozwiązania będącego odstępstwem od reguły generalnej ma służyć lepszej organizacji i koordynacji pracy kurialnej ${ }^{16}$.

Kończąc ten passus należy stwierdzić, iż twierdzenia kanonistów przekonujących, iż z zapisu kan. 51 KPK można wnosić, że pisemność dekretu jest wymogiem wymaganym do ważności aktu jest zwykłym uproszczeniem. Powoływanie się w argumentacji za tą tezą przez autorów hiszpańskiego podręcznika prawa administracyjnego na dyspozycję kan. $54 \$ 2$ KPK nie w pełni jest uzasadnione. Regulacja ta bowiem odnosi się tylko jednej hipotezy jaką jest powierzenie realizacji dekretu wykonawcy. Krytykując taki sposób wykładni W. Aymans i K. Mörsdorf uważają go za nadinterpretację. Zwracają oni uwagę, że w kan. $54 \$ 2$ KPK nie idzie o formę dekretu, ale o sposób doręczenia tego aktu ${ }^{17}$.

\footnotetext{
${ }^{14}$ T. Amann, Der Verwaltungsakt, dz. cyt., s. 33-34.

${ }^{15}$ Por. F. Ramos, Le diocesi nel Codice di diritto canonico. Studio giuridico pastorale sulla organizzazione ed raggruppamenti delle Chiese particolari, Roma 1997, s. 367; J. Miras, J. Canosa, E. Baura, Compendio, dz. cyt., s. 147.

${ }^{16}$ Por. G. Bier, Volk Gottes: Innere Ordnung der Teilkirche, w: Münsterischer Kommentar zum Codex Iuris Canonici, red. K. Lüdicke, t. 4, Essen 1985, ad 474, n. 1 .

${ }^{17}$ W. Aymans, K. Mörsdorf, Kanonisches Recht, dz. cyt., s. 240. Autorzy komentarza skrytykowali taki sposób wykładni dokonany przez Heimlera i Pree’a. Stwierdzili oni: „Dabei wird aber m. E. C. $54 \$ 2$ überinterpretiert, denn hier geht nicht um die Festlegung der Schriftform, sondern um die Aushändigung des Schriftstück [...]".
} 


\section{Motywacja dekretu}

Z treści kan. 51 KPK wynika, że dekret powinien zawierać przynajmniej ogólną motywację, jeśli zawierałby decyzję. Wymóg o którym mowa jest nowy. Zdaniem kanonistów, to nowatorskie ujęcie pozostaje w ścisłym związku z nieco odmiennym podejściem prawodawcy kościelnego do sprawy wydawania dekretu. Obecnie bowiem w przyjętych rozwiązaniach systemowych porzucono koncepcję w której adresat aktu administracyjnego był pojmowany w kategoriach poddanego. W tym ujęciu koncepcyjnym forma aktu miała charakter prośby. Zgodnie z wówczas przyjętymi regułami, władza kościelna wydając akt w sposób wolny i nieskrępowany prawami wiernych odpowiadała na prośbę wiernego. Sytuacja w tej materii uległa zmianie wraz z wprowadzeniem możliwości wniesienia rekursu przeciwko aktowi administracyjnemu. $\mathrm{Z}$ tego powodu dekrety poszczególne powinny być umotywowane.

Jak już wiadomo, obecnie sporządzenie motywacji jest niezbędne w przypadku dekretu zawierającego decyzję. Funkcjonowanie takiego rodzaju dekretu przewidziano w kan. $48 \mathrm{KPK}$. W regulacji tej stwierdzono, że na mocy tego aktu ma miejsce decyzja, bądź powierzenie.

Zdaniem E. Labandeiry, istnieje pewna różnica pomiędzy powierzeniem a decyzją. Powierzenie ze swej natury nie generuje sytuacji konfliktowej. Mechanizm jego funkcjonowania polega na wykorzystaniu odpowiednich środków w celu zaspokojenia pewnej konieczności. $\mathrm{W}$ tej hipotezie nie występuje konflikt pomiędzy zastosowanymi środkami a określonymi prawami lub też interesami. W Kodeksie z 1983 r. ta kategoria odnosi się do powierzenia urzędu kościelnego.

Decyzja natomiast zakłada rozwiązanie bądź konfliktu pomiędzy osobami, bądź też napięcia występującego w procedurze kontradyktoryjnej ${ }^{18}$.

\footnotetext{
${ }^{18}$ E. LabAndeira, Trattato, dz. cyt. s. 382: „Il can. 48, riferendosi al contenuto di un decreto, distingue tra la decisione e il fare una provvisione. Provvedere significa impiegare i mezzi adatti ad una necessità; nel Codice questo termine si impiega per la collazione di uffizi (cc. 146 ss.). Per sua natura, questo termine non indica un'attività che genera conflitto ma fa pensare a quella primaria attività che l'Amministrazione
} 
Według komentatorów, motywacja zamieszczona w dekrecie powinna zawierać racje wydania tego aktu; te zaś powinny wskazywać na fundamenty prawne i faktyczne, a także cel przedmiotowy i motywy drugorzędne, które skłoniły władzę kościelną do działania, a które mogą wzmocnić lub osłabić cel przedmiotowy ${ }^{19}$.

W myśl doktryny, konieczność podania motywacji pozostaje w ścisłym związku z jednym z naczelnych pryncypiów kanonicznego porządku prawnego, jakim jest zasada legalności. Wprowadzenie takiego rozwiązania ma z jednej strony zapobiec nadużyciom i wydawaniu decyzji arbitralnych ${ }^{20}$, z drugiej zaś ma umożliwić skorzystanie z instrumentu jakim jest rekurs przeciwko aktowi administracyjnemu ${ }^{21}$. Przy tym należy zauważyć, iż już w kan. $6 \$ 2$ SCPA wskazywano, iż dekret powinien zawierać motywacje, poza szczególnymi przypadkami (gravissima ratio), które usprawiedliwiałyby jego niezamieszczenie (Decretum scripto feratur, expressis, saltem summarie, motivis; quo si forte gravissima ratio obstet, ne motiva patefiant).

$\mathrm{W}$ analizie poruszanego problemu nie można pominąć jeszcze jednego wątku wiążącego z sumarycznym podaniem motywacji. Analizując polskie tłumaczenie kan. 51 KPK trzeba zwrócić uwagę, iż tłumacz łacińskie „saltem summarie” oddał za pomocą zwrotu „przynajmniej ogólnej motywacji”. Najprawdopodobniej sugerował się on znaczeniem „w ogólności” łacińskiego słowa „summarie” zamieszczonym w „Słowniku kościelnym łacińsko-polskim”, opracowanym przez A. Jougana ${ }^{22}$. Należy dodać, że polski tłumacz kodeksowy

pone in essere di propria iniziativa e nell'essere generale. Le decisioni invece, suppongono la soluzione di un conflitto tra due persone, siano queste privati oppure un privato e un soggetto pubblico come nel ricorso gerarchico (c. 1739); in oltre le decisioni suppongono la soluzione di un procedimento in contradditorio [...]".

19 Tamże, s. 381

${ }^{20}$ P. Pinto, De normis generalibus, dz. cyt., s. 39; V. De Paolis, A. D’Auria, Le norme generali di Diritto Canonico. Commento al Codice di Diritto Canonico, Roma 2008, s. 216.

${ }^{21}$ Por. L. Chiappetta, Il Codice di Diritto Canonico. Commento giuridico - pastorale, Roma 1996, s. 101.

${ }^{22}$ Por. A. Jougan, Słownik kościelny łacińsko - polski, Warszawa 1992, s. 659. 
był niekonsekwentny. Termin „summarie” bowiem występuje m. in. w takich regulacjach, jak kan. $699 \$ 1$ i 1617 KPK. W obu tych kanonach został on przetłumaczony jako ,sumaryczny”.

Wydaje się, iż polski desygnat terminu „W ogólności” nie odpowiada myśli prawodawcy (mens legislatoris) (kan. $17 \mathrm{KPK})$. J. Sondel w „Słowniku języka łacińskiego dla prawników i historyków” stwierdził, iż jednym ze znaczeń łacińskiego przymiotnika „summarius” jest „krótko ujęty”23. Podobne znaczenie ma termin "sumaryczny” w „Małym słowniku języka polskiego”. Jego desygnatami bowiem są: „sumujący ogół wiadomości o czymś; skrócony, zwięzły treściwy”24. W „Słowniku języka polskiego PWN” natomiast pod tym pojęciem rozumie się „zawierający wszystkie elementy czegoś lub podsumowujący ogół wiadomości o czymśn ${ }^{\prime 25}$. Znaczenia funkcjonujące w słownictwie polskim korespondują z kanonistycznym pojmowaniem tego zwrotu. Zastanawiając się nad znaczeniem normatywnego „saltem summarie" komentatorzy podkreślają, iż nie należy pojmować go szeroko, abstrakcyjnie czy też ogólnikowo. Przekonują oni, iż ustawodawca posiłkując się nim chciał wskazać, że idzie o motywację, która ma ukazać racje przemawiające za wydaniem aktu. Ponadto, piszą oni, iż w tym wypadku nie chodzi o wyczerpujące ukazanie motywów, lecz o przedstawienie w sposób streszczony racji wydania aktu ${ }^{26}$. Dekret

\footnotetext{
${ }^{23}$ Por. J. Sondel, Stownik języka łacińskiego dla prawników i historyków, Kraków 1997, s. 918.

${ }^{24}$ Por. Sumaryczny, w: Mały słownik języka polskiego, red. S. Skorupski, H. Auderska, Z. Łempicka, Warszawa 1969, s. 788.

${ }^{25}$ Por. Sumaryczny, w: Słownik języka polskiego PWN, red. L. Drabik, A. Kubiak Sokół, E. Sobol, L. Wiśniewska, wyd. III, Warszawa 1996, s. 975.

${ }^{26}$ J. Miras, J. Canosa, E. Baura, Compendio, dz. cyt., s. 199: „El c. 51 esige que se exponga la motivación «al menos sumariamente». Cabe subrayar que ese inciso no puede interpretarse como si bastara motivar «vagamente», «abstractamente», o "genéricamente» los decisiones: se pide una motivación que explique qué razones ha apreciado la autoridad y cuáles no ha considerado relevantes para decidir de ese modo en ese caso. Otra cosa ese que tal motivación no requiera un desarrollo exhaustivo del racionamiento, sino que baste enunciarla de manera resumida, es decir sumariamente".
} 
powinien zawierać streszczone motywy faktyczne i prawne podejmowanej decyzji ${ }^{27}$.

Na marginesie należy dodać, iż w znanym powszechnie w Polsce hiszpańskim „Komentarzu” Uniwersytetu z Nawarry nie zmodyfikowano treści kan. $51 \mathrm{KPK}$; przejęto ją bowiem z przekładu zatwierdzonego przez Konferencję Episkopatu ${ }^{28}$. Nieco odmiennie natomiast, a zarazem jak się wydaje poprawnie, przetłumaczono kan. 51 KPK w pierwszym tomie „Komentarza do Kodeksu Prawa Kanonicznego”, zredagowanego przez J. Krukowskiego i R. Sobańskiego; normatywne „saltem summarie” bowiem oddano za pomocą zwrotu „przynajmniej w sposób sumaryczny"29.

$\mathrm{W}$ interpretacji poruszanego problemu należy poruszyć jeszcze kwestię pominięcia wymogu dotyczącego motywacji dekretu. Kanoniści pytają: jakie następstwa wywołuje pominięcie motywacji? Odpowiadając na to pytanie podkreślają oni, iż nie skutkuje ono nieważnością dekretu, ale wiąże się z jego nielegalnością. Twierdzenie to wynika z przesłanki, iż zapis kan. 51 KPK nie spełnia wymogów wspomnianego już kan. $10 \mathrm{KPK}$, traktującego o ustawach unieważniających i uniezdalniających ${ }^{30}$.

W obowiązującej kodyfikacji występują regulacje w których podanie motywacji wymagane jest do ważności aktu. I tak w kan. 699 $\$ 1$ KPK prawodawca wymaga do ważności, aby dekret wydalający z instytutu życia konsekrowanego zawierał przynajmniej sumarycznie motywację prawną i faktyczną ${ }^{31}$. Podobnie i w kan. 1617 KPK stwierdzono, że dekrety wydawane przez sędziego, poza tymi, które mają charakter zwykłego zarządzenia, nie uzyskują skuteczności prawnej,

\footnotetext{
${ }^{27}$ H. Soch A, Allgemeine Normen, dz. cyt., ad 51, 5.

${ }^{28}$ Por. kan. 51 KPK, w: Kodeks Prawa Kanonicznego. Komentarz, red. P. Majer, Kraków 2011, s. 101.

${ }^{29}$ Por. kan. 51 KPK, w: J. Krukowski, R. Sobański, Komentarz, dz. cyt., s. 114.

${ }^{30}$ W. Aymans, K. Mörsdorf, Kanonisches Recht, dz. cyt., s. 240; P. Pinto, De normis generalibus, dz. cyt., s. 39; J. Miras, J. Canosa, E. Baura, Compendio, dz. cyt., s. 199.

${ }^{31}$ E. Labandeira, Trattato, dz. cyt., s. 382.
} 
jeśli przynajmniej sumarycznie nie podają motywów lub nie odsyłają do motywów podanych w innym akcie ${ }^{32}$.

Należy dodać, iż pomimo przyjętego rozwiązania w kan. $51 \mathrm{KPK}$, zgodnie z którym niezamieszczenie motywacji nie powoduje nieważności dekretu, to jednak pominięcie jej niesie za sobą pewne negatywne następstwa. W pierwszym rzędzie wydany w ten ten sposób umożliwia zaskarżenie takiej decyzji za pomocą rekursu ${ }^{33}$.

Należy też przypomnieć, iż jeszcze w „Relatio complectens” z 1981 r. sugerowano, że po zwrocie „feratur expressis” należy dodać „jeśli zawiera decyzję”; w tym kontekście przekonywano, iż w tej hipotezie absolutnie powinna być zamieszczona motywacja ${ }^{34}$. Z treści kan. 51 KPK jednak wynika, iż w ostatniej fazie kodyfikacyjnej odstąpiono od tego zamiaru.

\section{Zakończenie}

Zapis kan. 51 KPK tylko z pozoru nie powinien komentatorom nastręczać większych trudności interpretacyjnych. Analizy przeprowadzone w tym opracowaniu wykazały, że tak jednak nie jest. Konieczność wydania dekretu na piśmie nie jest oczywistością. Dyspozycja bowiem kan. 51 KPK nie spełnia kryterium określonego w kan. 10 KPK dotyczącego ustaw unieważniających i uniezdalniających. Jest prawdą, że forma pisemna aktu jest gwarantem pewności i bezpieczeństwa aktów administracyjnych, a także jest konieczna dla celów dowodowych. Dlatego też w praktyce administracyjnej powinno się dążyć do tego, aby dekrety były wydawane na piśmie. $Z$ badań przeprowadzonych w tym artykule wynika, iż w kanonicznym porządku prawnym występują regulacje, które spełniają warunki określone w kan. 10 KPK. Taka technika legislacyjna

\footnotetext{
${ }^{32}$ V. De Paolis, A. D’Auria, Le norme generali, dz. cyt., s. 216.

${ }^{33}$ J. Miras, J. Canosa, E. Baura, Compendio, dz. cyt., s. 199.

${ }^{34}$ Por. Relatio complectens synthesim animadversionum ab Em.mis atque Exc.mis patribus commisionis ad novissimum Schema Codicis Iuris Canonici exhibatarum, cum responsionibus a Secretaria et consultoribus datis, Typis Polyglotis Vaticanis 1981, s. 28: „Ex officio: post verba «feratur expressis» addatur «si agatur de decisione» quia tantum his in casibus requiritur absolute expositio motivorum”.
} 
została zastosowana w kan. $474 \mathrm{KPK}$, zgodnie z którym akta kurii diecezjalnej, aby uzyskać skuteczność prawną do ważności powinny być podpisane przez ordynariusza. Na marginesie należy dodać, iż obecnie przyjęty charakter rozwiązań co do pisemności dekretów poszczególnych był postulowany w trakcie prac kodyfikacyjnych. Jeden z konsultorów proponował bowiem następujący zapis: akt administracyjny powinien być wydany na piśmie, ale nie do ważności ${ }^{35}$.

Kolejny problem związany z wykładnią kan. 51 KPK stanowi kwestia motywacji. Z treści kan. $51 \mathrm{KPK}$ wynika, iż w dekrecie powinna być podana motywacja, jeśli zawiera decyzję. Wydaje się, iż z punktu widzenia praktyki administracyjnej najbardziej stosowne byłoby przyjęcie rozwiązania, aby każdy dekret zawierał powód jego wydania. Według T. Jiméneza Urresti, podanie sumarycznej motywacji $\mathrm{w}$ dekrecie jest gwarantem jego obiektywności ${ }^{36}$.

W obowiązującej kodyfikacji prawodawca domaga się podania motywacji w dekretach zawierających decyzję. Według kanonistów, spełnienie tego wymogu wiąże się z faktem, iż dekret wydany w formie decyzji zakłada rozwiązanie konfliktu istniejącego pomiędzy osobami. Niewypełnienie tego wymogu nie skutkuje nieważnością dekretu, ale wiąże się z jego nielegalnością, ponieważ zapis kan. 51 KPK nie spełnia warunków określonych w kan. 10 KPK.

\section{The form of a singular decree in the canonical legal order (Can. 51 CIC)}

The author of the presented article carried out a thorough interpretation of can. $51 \mathrm{CIC}$. The focus of his attention were 2 issues: the question of a written form of a decree and the problem of motivation behind it. According to his analysis, the obligation to issue a decree in writing is not obvious.

\footnotetext{
${ }^{35}$ Por. Communicationes 17(1985), s. 49: „Alius vero Consultor consentit cum Secretario Adiuncto, sed aestimat illos tantum actus administrativos scriptis concendendos qui effectum iuridicum habeant, sed ad validitatem non requiri ut scriptsi fiant"; T. Amann, Der Verwaltungsakt, dz. cyt., s. 34.

${ }^{36}$ Por. T. Jiménez Urresti, Comento al can. 51 CIC, w: Código de Derecho Canónico. Edición bilingüe comentada, red. L. De Echeveria, Madrd 1985, s. 51.
} 
The disposition included in can. 51 CICI does not accord with the criteria determined in can. $10 \mathrm{CIC}$ which concerns invalidating and disqualifying laws. The author proved that the canonical legal order includes regulations concerning the written form of decrees which meet the conditions defined in can. 10 CIC. Such a legislative mechanism was used in can. 474 CIC according to which acts of the curia in order to have juridic effect must be signed by the ordinary. The author believes that the written form guarantees the validity and security of administrative acts and is necessary for evidential purposes.

Another focus of the author's attention was the question of motivation of a decree. As he believes, from the perspective of administrative practice, the most appropriate solution would be for every issued act to include its motivation. In consequence, the addressee of an act would learn about both legal and actual reasons behind a particular decision.

The author proved that not meeting the requirement concerning the motivation of a decree does not result in its invalidity but makes it illegal since the norm included in can. $51 \mathrm{CIC}$ does not meet the conditions codified in can. 10 CIC.

SŁOWA KLUCZOWE: poszczególny dekret, forma poszczególnego dekretu, kanoniczny porządek prawny.

KEY WORDs: singular decree, the form of a singular decree, canonical legal order.

\section{Nota o Autorze:}

Ks. PROF. DR HAB. GINTER DZIERżon - profesor zwyczajny, kierownik Katedry Teorii i Norm Ogólnych Prawa Kanonicznego na Wydziale Prawa Kanonicznego UKSW. Jest autorem ponad 200 opracowań naukowych z zakresu prawa małżeńskiego, norm ogólnych prawa kanonicznego oraz teorii prawa. 